DOI https://doi.org/10.18551/rjoas.2018-06.18

\title{
THE INFLUENCE OF FEAR APPEALS ON CUSTOMER'S MOTIVATION TO BUY CIGARETTES: SURVEY CONDUCTED TO JUVENILES AGED 13-19 YEARS OLD IN MALANG CITY
}

\author{
Irawan Ari*, Firdias Adil, Mawardi M. Kholid \\ Faculty of Administrative Science, University of Brawijaya, Indonesia \\ ${ }^{*}$ E-mail: ari.irawan@ub.ac.id
}

\begin{abstract}
This research aimed at partially and simultaneously describing the influence of fear, threat, and efficacy on customer's motivation to buy cigarettes. This research applied survey methodology with quantitative approach. The population of this research was a young smoker aged 13 until 19 years old in Malang City. The sample of this research amounted to 116 respondents and the technique applied was purposive sampling. The instrument chosen to carry out this research was a questionnaire in form of a question with Likert scale. Data analysis adopted to conduct this research was descriptive analysis, multiple regression, simultaneous test $(F)$ and partial test $(t)$. The research result revealed that: partially, fear $(X 1)$ variable had a positive but not significant influence on consumer's motivation to buy cigarettes $(Y)$; threat $(X 2)$ variable had a negative and no significant influence on consumer's motivation to buy cigarettes $(Y)$; variable of efficacy $(X 3)$ had a negative and no significant influence on consumer's motivation to buy cigarettes $(Y)$. Simultaneously, fear (X1), threat (X2) and efficacy (X3) variable had no simultaneous influence on consumer's motivation to buy $(\mathrm{Y})$. According to that result, fear is the one and only variable having positive value although very low.
\end{abstract}

\section{KEY WORDS}

Fear appeals, fear, threat, efficacy, motivation to buy cigarettes.

Indonesia is the fourth biggest cigarette consumer country after China, Russia, and the United States (Global Market Information database: 2014). That data seems like in accordance with the reality in Indonesia. We can see that reality in Indonesia in which the student of elementary school until an elderly is common to consume cigarettes. The data collected in 2013 quoted by Global Youth Tobacco Survey (2014: 5) presented the age group of total young smokers based on their age. The data shows that $9.5 \%$ of the children aged 10-14 years old are a smoker and $50.3 \%$ aged $15-19$ age years old are too. The data indicate that the juvenile is fragile to consume cigarette at that young age. Baer \& Corado (in Atkinson,1999) quoted by Nurrahmah (2014: 78) have described that juvenile considered smoking is a symbol of virility and glamour, that was way they were frequently interested in following smoking behavior.

One of the ways that can be made to solve that social problem like smoking behavior is through a social marketing campaign. The social marketing campaign is one of the areas of expertise from marketing focused to influence consumer behavior to the better way (Kotler \& less, 2008: 7). There are many things which can be influenced by social marketing, i.e. remaking health, environment, bad community behavior, etc. One of the applications of social marketing is using persuasive communication. Setiadi (2003: 172) defined persuasive as utilizing information about the circumstance of psychology, sociology and the culture of the communicant, to influence and achieve the realization of what expected by the message.

One of the techniques carried out in persuasive communication is through fear appeals. Fear appeals are one of the methods to deliver the message to the consumer by targeting their fear emotional so they will cancel their intention to buy something. Fear appeals try to change individual or society's behavior by utilizing target's emotional feeling using those fear appeals. Witte (1992, as quoted by Bates, 2014: 19-22) proposed 3 
elements that stimulate someone's fear, i.e. fear, threat, and efficacy. Those three elements influence the appearance of someone's feelings about something.

The form of application of fear appeals has been conducted in various campaigns in the world. One of the examples is what in Indonesia's cigarette packs. The Regulation of the Ministry of Health of The Republic of Indonesia Number 28 Year 2013 regulating the inclusion of health warnings and health information on cigarette packs. That regulation is the follow-up of the Government Regulation Number 109 Year 2012, aiming for material security containing addictive substances in the form of cigarette product for community health. Indonesia government obliges cigarette producer to list a scary image on cigarette packs, like Figure 1.

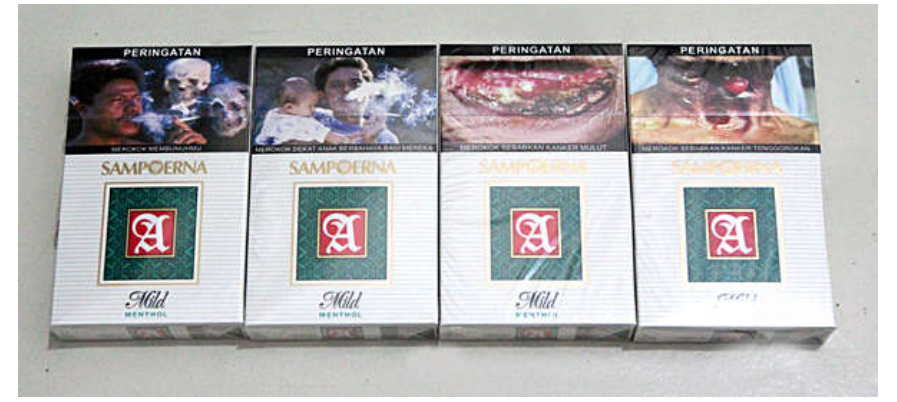

Figure 1 - Surya Pro Pack with Scaring Image (Source: kompasiana.com)

Those cigarette packs are categorized fear appeals, applying stimulation of fear to curb cigarette consumption in Indonesia. Government role to determine the policy of cigarette packs with those scary images are one of the forms of the application of social marketing upstream (Cheng et al., 2011: 16).

\section{LITERATURE REVIEW}

Fear Appeals. Definition of fear appeals according to Mowen and Minor (2002: 415, as quoted in Sanjaya and Kusasih, 2012: 62) is a message to identify that consumer is like in an unfavorable situation if they fail to use the offered product". While Sanjaya and Kusasih (2012: 62) have defined fear appeals as a call by utilizing someone's fear or inconvenience for negative consequence if not using the offered product. Fear appeals advertisement basically aims to motivate target to manage collected information. Within the fear appeals, there is a consequence implied on the emotional side, i.e. (Shimp, 2003: 474) negative consequence if does not use the product being advertised and negative consequence from bad behavior (i.e. drink-driving).

Witte (1992, as quoted by Bates, 2014: 19) proposed that there are three elements that stimulate someone's fear appeals, i.e. fear, threat, and efficacy.

Motivation to Buy Cigarette. Merle J. Moskowits as quoted by Engel et al., (1994, in Setiadi, 2003: 25 -26) defined motivation in general as an initiation and behavior control as well; in addition, motivation learning can be defined as learning from someone's behavior. Suryani (2008: 27) proposed that motivation process happens because of needs, not-fulfilled willingness or expectation and causes a tension.

The aims of consumer motivation as explained by Setiadi (2003: 31) are increasing satisfaction, maintaining loyalty, efficiency, effectiveness and creating a harmonic relationship between producer and consumer.

According to that motivation, Suryani (2008: 28) designed that there is an element involved in this motivation process, including needs, behavior, and purpose.

Hypotheses:

$\mathrm{H}_{1}$ : Fear variable has a partial and significant influence on the motivation to buy cigarette among the young people.

$\mathrm{H}_{2}$ : Threat variable has a partial and significant influence on the motivation to buy cigarette among the young people 
$\mathrm{H}_{3}$ : Efficacy variable has a partial and significant influence on the motivation to buy cigarette among the young people.

$\mathrm{H}_{4}$ : Fear, Threat and Efficacy variable have a joint and significant influence on the motivation to buy cigarette among the young people.

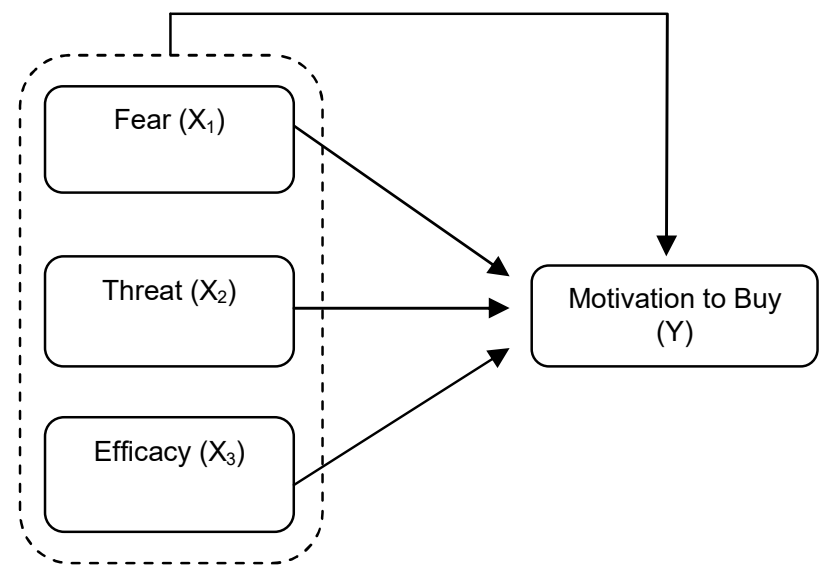

Figure 2 - Hypotheses Model

\section{METHODS OF RESEARCH}

The method practiced to carry out this research was a survey method with quantitative approach. The population of this research was a young smoker aged 13 until 19 years old in Malang city. The sample of this research was mostly a young smoker in Malang City amounted to 116 respondents and analyzed using multiple regression and SPSS 2.3 for Windows.

Purposive sampling was a sampling technique applied in this research and spreading questionnaire to collect the data (offline questionnaire) to the young smoker aged 13 until 19 years old in Malang city. The instrument chosen to conduct this research was questionnaire which has been compiled in accordance with variables indicator that has been determined before. Data analysis used in this research was descriptive analysis, multiple regression, simultaneous test $(F)$ and partial test $(t)$.

\section{RESULTS AND DISCUSSION}

The highest number of the smokers were those aged 17 amounted to 24 people $(20.7 \%)$. In addition, the vast majority of respondents were man amounted to 110 people $(94.8 \%)$ and women of 6 people $(5.2 \%)$. That result supports the statement of Baer \& Corado (in Atkinson, 1999) as quoted by Nurrahmah (2014: 78) proposing that smoking is the symbol of virility and glamour for young people.

The data collected from this research shows an alarming circumstance. Almost all the respondents' first smoking experience was in Junior High School (SMP) amounted to 63 people $(54.3 \%)$. That data was also in accordance with Global Youth Tobacco Survey (2014: 5) presenting age group from total young smokers based on their age. The data shows that $9.5 \%$ of the children aged $10-14$ years old are a smoker and $50.3 \%$ aged $15-19$ age years old are too. From that data can be known that the lack of monitoring and learning role from family or related party about the bad impact of cigarette consumed.

Coefficient of determination obtained in this research was indicated by Adjusted $R$ square of -0.009 or $-0.9 \%$. This reveals that Fear $\left(X_{1}\right)$, threat $\left(X_{2}\right)$ and Efficacy $\left(X_{3}\right)$ variable have an influence of $-0.9 \%$ on the Motivation to Buy. That data shows that Fear $\left(X_{1}\right)$, Threat $\left(X_{2}\right)$ and Efficacy $\left(X_{3}\right)$ variable have no contribution to the Motivation to Buy $(Y)$.

Coefficient of correlation value collected in this research was by 0.131 . Coefficient of correlation value by 0.131 was in the category of $0.00-0.199$. That circumstances show that 
independent and dependent variable has a very low relationship. It concludes that the relationship between independent variable and dependent variable is positive even though the relationship is very low, so when Fear $\left(X_{1}\right)$, Threat $\left(X_{2}\right)$ and Efficacy $(X 3)$ variable are increased, Motivation to Buy $(\mathrm{Y})$ will increase too but not significant or too big.

The result of $F$ significance value amounted to 0.585 . Since $F$ significance value was $(0.585)>(0.05)$ so this case shows that $\mathrm{H}_{0}$ and $\mathrm{H}_{\mathrm{a}}$ were rejected so can be concluded that Fear $\left(X_{1}\right)$, Threat $\left(X_{2}\right)$ and Efficacy $\left(X_{3}\right)$ variable have no simultaneous and significant influence on the variable of Motivation to Buy $(Y)$.

T-test result between Fear $\left(\mathrm{X}_{1}\right)$ and Motivation to buy $(\mathrm{Y})$ variable result in $\mathrm{t}$ significant value by 0.325 . Since $t$ significance is $(0.325) \geq \alpha(0.05)$ so this circumstance shows that $H_{0}$ is accepted and $\mathrm{H}_{\mathrm{a}}$ is rejected. It concludes that partially; Fear $\left(\mathrm{X}_{1}\right)$ variable has no significant influence on the Motivation to Buy $(\mathrm{Y})$. The result of t-test between Threat $\left(\mathrm{X}_{2}\right)$ and Motivation to Buy $(\mathrm{Y})$ variable result in $\mathrm{t}$ significance value amounted to 0.714 . Since $t$ significance value is $(0.714) \geq \alpha(0.05)$ so this case shows that $H_{0}$ is accepted and $H_{a}$ is rejected. The conclusion is Threat $(\mathrm{x} 2)$ variable partially has no significant influence on the Motivation to Buy $(\mathrm{Y})$ variable. T-test result between Efficacy $\left(\mathrm{X}_{3}\right)$ and Motivation to Buy $(\mathrm{Y})$ variable result in $t$ significance value of 0.323 . Since $t$ significance is $(0.323) \geq \alpha(0.05)$ so this case demonstrates that $\mathrm{H}_{0}$ is accepted and $\mathrm{H}_{\mathrm{a}}$ is not. It concludes that partially Fear (X1) variable has no significant influence on Motivation to Buy $(\mathrm{Y})$ variable.

\section{CONCLUSION AND SUGGESTIONS}

There is a positive but not significant influence of fear on consumer's motivation to buy. Later on, threat and efficacy have a negative influence on the motivation to buy. The last conclusion is there is no simultaneous influence on fear, threat, and efficacy on young smoker's motivation to buy.

Cigarette producer should re-design the message on cigarette packs so it has more impact on the smoker especially the young ones. Later on, the government is expected able to revise or strengthen the law on smoking prohibition for young people under 18 years old, or penalty given to those buying cigarette. The last suggestion for a further researcher is expected able to develop this research by studying other factors that can influence consumer's motivation to buy. Future researcher also can apply another method to study consumer's motivation to buy and also expected able to cover a larger area with much more sample of respondents to have more valid generalization towards respondents.

\section{REFERENCES}

1. Bates, Meagan. 2014. Fear as a Motivator in Health Campaigns. Clemson University, Clemson: All Theses. Paper 1935.

2. Cheng, Hong, Philip Kotler \& Nancy R. Lee. 2011. Social Marketing for Public Health: Global Trends and Success Stories. London: Jones and Bartlett Publishers.

3. Kotler, 2008. Social Marketing: Influencing Behaviors for Good. 3rd. Ed. Sage Pub., Inc.

4. Nururrahmah. 2014. Pengaruh Rokok terhadap Kesehatan dan Pembentukan Karakter Manusia. Jurnal Prosiding Seminar Nasional, 01 (1): 77 - 84.

5. Sanjaya, Dhida Surya \& Ida Ayu K. R. Kusasih. 2012. Pengaruh Fear Appeals, Endorser dan Jingle dalam Iklan Suzuki Nex di Televisi Versi Band Sm*sh terhadap Respon Konsumen. Jurnal Graduasi, 28 (November): 59 - 70.

6. Setiadi, Nugroho. J. 2003. Perilaku Konsumen: Perspektif Kontemporer pada Motif, Tujuan dan Keinginan Konsumen, Revised Edition. Jakarta: Prenadamedia Group.

7. Shimp, Terence A. 2003. Periklanan Promosi dan Aspek Tambahan Komunikasi Terpadu, Fift Edition. Translated by R. Sahrial \& D. Anikasari. Jakarta: Erlangga.

8. Suryani, Tatik. 2008. Perilaku Konsumen: Implikasi pada Strategi Pemasaran. Edisi Pertama. Yogyakarta: Graha IImu. 